OPEN ACCESS

Edited by:

Olivier Vandenberg, Université libre de Bruxelles, Belgium

Reviewed by:

Hung Viet Trinh,

Henry M. Jackson Foundation for the Advancement of Military Medicine, Inc. (HJF), United States Ana Afonso,

University of São Paulo, Brazil

*Correspondence: Juan S. Leon juan.leon@emory.edu

Specialty section: This article was submitted to Infectious Diseases Surveillance, Prevention and Treatment, a section of the journal Frontiers in Public Health

Received: 31 October 2017 Accepted: 05 February 2018 Published: 23 February 2018

Citation:

Van Pelt AE, Quiñones B, Lofgren HL, Bartz FE, Newman KL and Leon JS (2018) Low Prevalence of Human Pathogens on Fresh Produce on Farms and in Packing Facilities: A Systematic Review.

Front. Public Health 6:40. doi: 10.3389/fpubh.2018.00040

\section{Low Prevalence of Human Pathogens on Fresh Produce on Farms and in Packing Facilities: A Systematic Review}

\author{
Amelia E. Van Pelt', Beatriz Quiñones' ${ }^{2}$ Hannah L. Lofgren', Faith E. Bartz', \\ Kira L. Newman ${ }^{1}$ and Juan S. Leon ${ }^{1 *}$
}

${ }^{1}$ Hubert Department of Global Health, Emory University, Atlanta, GA, United States, ${ }^{2}$ Produce Safety and Microbiology Unit, USDA/ARS/Western Regional Research Center, Albany, CA, United States

Foodborne illness burdens individuals around the world and may be caused by consuming fresh produce contaminated with bacterial, parasite, and viral pathogens. Pathogen contamination on produce may originate at the farm and packing facility. This research aimed to determine the prevalence of human pathogens (bacteria, parasites, and viruses) on fresh produce (fruits, herbs, and vegetables) on farms and in packing facilities worldwide through a systematic review of 38 peer-reviewed articles. The median and range of the prevalence was calculated, and Kruskal-Wallis tests and logistic regression were performed to compare prevalence among pooled samples of produce groups, pathogen types, and sampling locations. Results indicated a low median percentage of fresh produce contaminated with pathogens $(0 \%)$. Both viruses $(p$-value $=0.017)$ and parasites ( $p$-value $=0.033$ ), on fresh produce, exhibited higher prevalence than bacteria. No significant differences between fresh produce types or between farm and packing facility were observed. These results may help to better quantify produce contamination in the production environment and inform strategies to prevent future foodborne illness.

Keywords: farm-to-fork, pathogen, fruit, vegetable, herb, farm, packing facility

\section{INTRODUCTION}

The World Health Organization reported a global burden of 600 million cases of foodborne illness and 420,000 foodborne illness-attributed deaths in 2010 (1). The majority of foodborne illnesses result from viral pathogens, such as norovirus, succeeded by bacterial pathogens, such as Salmonella, and parasite pathogens, such as Cyclospora $(1,2)$. Foodborne illness may be caused by contaminated fresh produce [reviewed in Ref. (3-5)]. For example, from 2004 to 2013 in the United States, 36\% of cases of foodborne illnesses resulted from consumption of contaminated produce (6).

Fresh produce can become contaminated with human pathogens during harvesting on farms and packaging either in the field or in packing facilities $(7,8)$. For example, investigations into an outbreak of Salmonella in the United States in 2008 identified jalapeño farms in Mexico as the source of contamination $(9,10)$. Further, investigators of a norovirus outbreak in Denmark in 2010 concluded that lettuce from a producer in France caused the infection (11). In a third example, researchers traced the source of a multistate outbreak of Listeria monocytogenes in the United States in 2011 to contamination of cantaloupe in packing facilities in Colorado (12). Thus, produce may become contaminated in one region but affect consumers in other regions. 
Although outbreak data provides information on common pathogens and produce types involved in foodborne illness of the consumer, it often does not identify or quantify the source of contamination in the original setting at the farm or packing facility [reviewed in Ref. (3-5)]. This article aims to determine the prevalence of human pathogens (bacteria, parasites, and viruses) on fresh produce (herbs, fruits, and vegetables) on farms and in packing facilities worldwide through a systematic analysis of peer-reviewed literature published before August 2017.

\section{METHODS}

\section{Article Identification}

A search for peer-reviewed literature published in English or Spanish from the initial date of each database to July 2017 was performed in four databases: PubMed, Web of Science, Academic Search Complete, and Agricola. Variables were compiled to create a search string for produce type, farm or packing facility, prevalence data, pathogen type, and excluding common non-produce routes of contamination (Table 1). The initial search completed on November 2015 yielded 840 articles across all databases. An additional identical search completed on July 2017 yielded 127 new articles for a total of 967 articles across all databases.

\section{Article Screening}

After removing duplicate articles across databases, the remaining 706 articles were subjected to inclusion and exclusion criteria by two independent reviewers (Amelia E. Van Pelt and Hannah L. Lofgren), and discrepancies were reconciled through discussions or a third independent reviewer (Juan S. Leon). Inclusion criteria included articles with: (1) English or Spanish language, (2) produce samples tested that came from a farm or packing facility, (3) fresh produce samples that were not processed (e.g., not frozen, peeled, cut, or rinsed with disinfectant), (4) reported prevalence (percent or whole number) of human foodborne pathogens, and (5) produce samples that were individual (e.g., not composite). Exclusion criteria excluded articles that reported outbreaks, lab-based studies, non-human pathogens indicator organisms, insufficient information on whether it was sampled from a farm or packing facility or prevalence data, microorganisms not strongly associated with human (e.g., Enterobacter or Enterococcus), or non-foodborne pathogens (e.g., Raoultella terrigena, Tatumella terra, Pantoea agglomerans, Pseudomonads, Rahnella aquatilis, and Serratia fonticola). Application of inclusion and exclusion criteria resulted in 38 articles.

\section{Data Extraction}

From each of the selected 38 articles, data were extracted independently by two reviewers (Amelia E. Van Pelt and Hannah L. Lofgren), and discrepancies were documented and reconciled through discussion or a third independent reviewer (Juan S. Leon). Extracted data included: article title, first author, journal, publication date, pathogen(s) examined, produce examined, study city/state/region, study country, study contamination location, month/season of produce collection, laboratory detection $\operatorname{method}(\mathrm{s})$, and statistical measurement unit (e.g., percent or CFU). Further, in the article, if the same individual produce commodities were sampled from the same location and analyzed at one time using the same laboratory methodology, then they were defined as a group. For example, two separate farm visits where 12 cantaloupes per visit were sampled from the same farm location and analyzed at one time using the same laboratory methodology were considered two groups of cantaloupes for that article. From each article, the following data were extracted: the number of positive pathogen observations of each group (prevalence numerator), number of individual commodities tested at one time (prevalence denominator) of each group, and the group pathogen prevalence (prevalence numerator divided by prevalence denominator). When only numerator and denominator data were reported, reviewers manually calculated the pathogen prevalence.

\section{Statistical Analysis}

Descriptive analyses were performed using SAS version 9.4 (SAS Institute, Cary, NC, USA). The prevalence of human pathogens (bacteria, parasites, and viruses) on fresh fruits, herbs, and vegetables was estimated across groups. To account for the non-normal distribution and small sample size of data, the median and range across groups were calculated to more accurately measure the central tendency of the prevalence percentage. In addition, the

TABLE 1 | Overview of search string operations.

\begin{tabular}{|c|c|c|c|}
\hline Database & Search string & Search field & Article yield \\
\hline $\begin{array}{l}\text { Academic search } \\
\text { complete }\end{array}$ & $\begin{array}{l}\text { (vegetable }{ }^{\star} \text { OR fruit*) AND (farm* OR packing OR packag* OR process }{ }^{\star} \text { ) AND (prevalence OR contamination) AND } \\
\text { (Escherichia coli OR hepatitis OR salmonella OR norovirus OR botulinum OR pathogen* OR bacteria OR virus*) NOT } \\
\text { (meat OR dairy OR fish) }\end{array}$ & Abstract & 240 \\
\hline Agricola & $\begin{array}{l}\text { (vegetable }{ }^{\star} \text { OR fruit*) AND (farm* OR packing OR packag* OR process*) AND (prevalence OR contamination) AND } \\
\text { (Escherichia coli OR hepatitis OR salmonella OR norovirus OR botulinum OR pathogen* OR bacteria OR virus*) NOT } \\
\text { (meat OR dairy OR fish) }\end{array}$ & Abstract & 130 \\
\hline PubMed & $\begin{array}{l}\text { ((vegetable OR vegetables OR fruit OR fruits) AND (farm OR farms OR packing OR packag* OR process*) AND } \\
\text { prevalence AND (Escherichia coli OR hepatitis OR salmonella OR norovirus OR botulinum OR contaminat* OR } \\
\text { pathogen^ OR bacteria OR virus*) NOT (meat OR dairy OR fish)) }\end{array}$ & All fields & 348 \\
\hline Web of science & $\begin{array}{l}\text { ((vegetable\$ OR fruit\$) AND (farm\$ OR packing OR packag* OR process*) AND prevalence AND (Escherichia coli } \\
\text { OR hepatitis OR salmonella OR norovirus OR botulinum OR contaminat* OR pathogen\$ OR bacteria OR virus*) NOT } \\
\text { (meat OR dairy OR fish)) }\end{array}$ & Topic & 249 \\
\hline
\end{tabular}


sample location of the commodities tested was inferred based on the authors' description in the methods and categorized into farm and packing facility for analysis, and analyses were stratified by farm and packing facility. Commodities of the same genus were grouped together for analysis, but the Supplementary Materials include all commodities as separate species. Kruskal-Wallis tests and Steel Dwass tests, where appropriate, were completed to compare the continuous prevalence across pathogens, commodities, and farm vs packing facility. To compare the dichotomous prevalence ( $0 \%$ prevalence vs $>0 \%$ prevalence), logistic regression was performed. All groups were pooled for respective analyses, with the limitation that pooling data extracted from individual articles across regions, laboratory methods, and time may have widened the error and variability of the resulting estimates.

\section{RESULTS}

The initial search yielded 967 articles [PubMed (348 articles), Web of Science (249), Academic Search Complete (240), and Agricola (130)] (Figure 1). After removing 261 duplicate articles, 706 remained for further review. 648 articles were excluded as per criteria (see "Materials and Methods"); many studies occurred in markets and produce stands instead of farms and packing facilities. Through the data extraction process of 58 articles, 20 additional articles were excluded, because they did not contain sufficient information on pathogen prevalence, whether it was sampled from a farm or packing facility, or produce type to enable accurate analysis; most publications did not stratify their prevalence data by produce type. The remaining 38 articles contributed data to this review. Thirty-five articles sampled from farms, and eight articles sampled from packing facilities. Ten

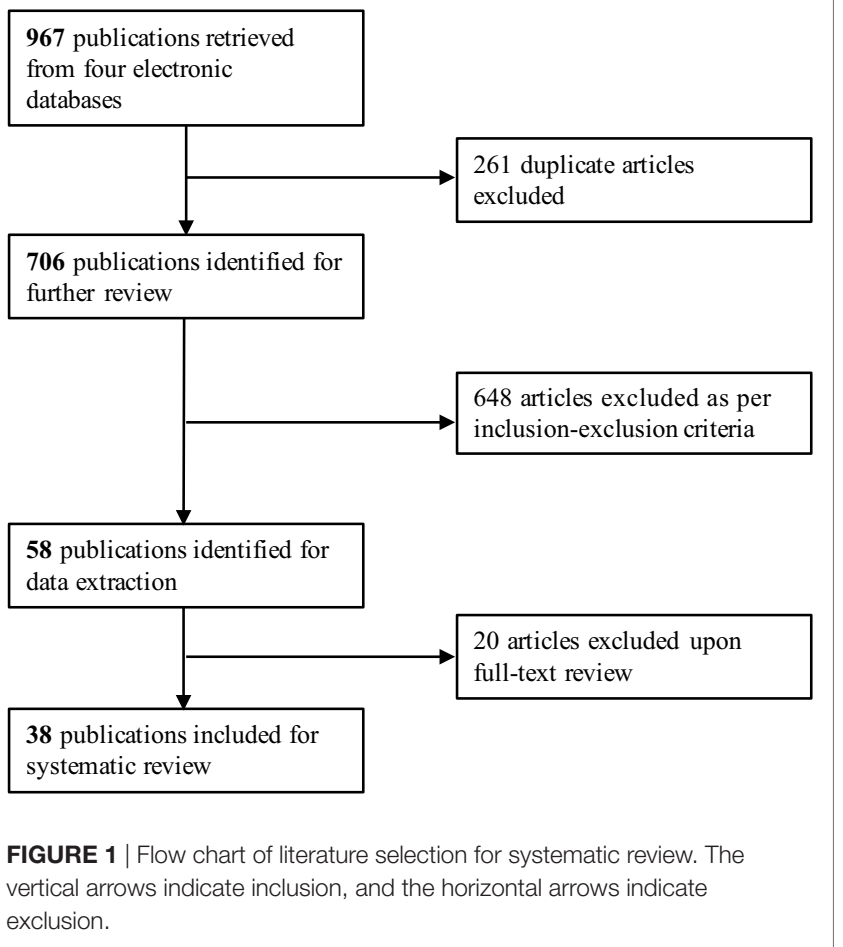

articles sampled from North America, 10 articles sampled from Asia, 9 articles sampled from Europe, and 7 articles sampled from Africa. Only one article sampled from South America. Among pathogens tested, Salmonella was tested the most $(61 \%, n=23$ articles) and among commodities tested, lettuce was sampled the most (37\%, $n=14$ articles).

\section{Pathogen Type}

To determine the prevalence of human pathogens on fresh produce, researchers extracted, or manually calculated, prevalence data from each article (see "Materials and Methods"). The median and range of the percent of positive samples across produce groups (see "Materials and Methods" for definition of a produce group) from farms and packing facilities were calculated (Tables 2 and 3). The majority of articles tested for bacteria, (84\%) followed by parasites (18\%) and viruses (5\%). Across farms and packing facilities combined (Tables 2 and 3), among bacteria, Campylobacter had the highest median prevalence $(25 \%, n=18)$, while pathogenic Escherichia coli (referred to as enterohemorrhagic E. coli (EHEC), Shiga toxin/verotoxin-producing E. coli (STEC/VTEC), or E. coli O26, O103, O111, O145, and O157:H7), Listeria, and Salmonella had the lowest median prevalence (0\%, $n=$ EHEC: 1, STEC/VTEC: 13, O26-O145:4, O157H7: 51, Listeria: 45, and Salmonella: 84). Among parasites, Giardia had the highest median prevalence (50\%, $n=13$ ), and Ascaris spp., Trichuris spp., and Toxocara spp. had the lowest median prevalence $(0 \%$, $n=40$ ). Among viruses, norovirus had the highest median prevalence of positive samples $(22 \%, n=9)$, while rotavirus had the lowest median prevalence $(0 \%, n=6)$. When pooling and comparing bacteria, parasites, and viruses to each other, the prevalence of viruses (Steel Dwass $=3.869, p$-value $=0.017$ ) and parasites (Steel Dwass $=3.541, p$-value $=0.033$ ) on fresh produce were both significantly higher than the prevalence of bacteria. When produce groups were reclassified to presence vs absence of pathogens, there was no significant difference in the percentage of groups that had pathogens among viruses, parasite, or bacteria (bacteria was the referent group; virus: OR 3.166, 95\% CI $0.813-12.329, p$-value $=0.154$; parasite: OR $1.378,95 \% \mathrm{CI}$ $0.879-2.161, p$-value $=0.527$ )

\section{Farms and Packing Facilities}

To contrast the prevalence of human pathogens on fresh produce between farms and packing facilities, researchers stratified the results by farms (Table 2) and packing facilities (Table 3). In this systematic review, the majority of articles (92\%) sampled from farms. When stratified by farm, the pathogens with the highest median prevalence, described in the preceding paragraph, did not change. The articles that sampled from packing facilities only tested for bacteria and viruses, not parasites. In contrast to the pathogen prevalence on farms, in packing facilities, E. coli $\mathrm{O} 157: \mathrm{H} 7$ had the highest median prevalence among bacteria $(5.0 \%, n=2)$, and hepatitis A had the highest median prevalence $(11.1 \%, n=6)$ among all pathogens included. In packing facilities, Salmonella and Shigella were not detected, and rotavirus was rarely detected. Overall, there was no significant difference in the prevalence of pathogens between farms and packing facilities. 
TABLE 2 | Prevalence of pathogens on produce from farms by pathogen type.

\begin{tabular}{|c|c|c|c|c|}
\hline Pathogen & $\begin{array}{l}\text { Median prevalence }{ }^{\mathrm{a}} \\
\text { (range) }\end{array}$ & $\begin{array}{l}\text { Number } \\
\text { of groups } \\
\text { sampled }^{b}\end{array}$ & Sample country & Reference \\
\hline \multicolumn{5}{|l|}{ Bacteria } \\
\hline Bacillus cereus & $7.9(0-11.1)$ & 6 & Korea & (13) \\
\hline Campylobacter & $25.0(0-90.0)$ & 18 & Belgium, Malaysia & $(14,15)$ \\
\hline Escherichia coli O157:H7 & $0(0-1.6)$ & 51 & $\begin{array}{l}\text { Brazil, Korea, Multi-countryc, South Africa, Spain, } \\
\text { United States }\end{array}$ & $(13,16-22)$ \\
\hline E. coli O26, O103, O111, 0145 & 0 & 4 & Spain & (16) \\
\hline Enterohemorrhagic E. coli & 0 & 1 & Belgium & (23) \\
\hline Enteric E. colid & 0 & 13 & Greece, Japan, United States & $(24-26)$ \\
\hline Hafnia alvei & $10.0(0-20.0)$ & 2 & Netherlands, Poland & $(27,28)$ \\
\hline Listeria & $0(0-20.0)$ & 43 & $\begin{array}{l}\text { Germany, India, Korea, Multi-countryc, Poland, South } \\
\text { Africa, Spain, United States }\end{array}$ & $(13,16-18,22,29-33)$ \\
\hline Salmonella & $0(0-60.0)$ & 80 & $\begin{array}{l}\text { Belgium, Brazil, China, Egypt, Eritrea, Germany, Japan, } \\
\text { Kenya, Korea, Lebanon, Mexico, Multi-countryc, Poland, } \\
\text { South Africa, Spain, United States }\end{array}$ & $\begin{array}{c}(13,16-21,23,24,26 \\
28,30,33-41)\end{array}$ \\
\hline Shigella & $0(0-8.3)$ & 7 & Eritrea, United States & $(37,38)$ \\
\hline Staphylococcus aureus & $5.5(1.0-7.9)$ & 8 & China, Korea & $(13,39)$ \\
\hline \multicolumn{5}{|l|}{ Parasite } \\
\hline Ascaris spp. & $0(0-33.3)$ & 40 & Poland & $(42)$ \\
\hline Cryptosporidium & $8.9(0-50.0)$ & 13 & Cambodia, Iran & $(43,44)$ \\
\hline Cyclospora & $10.4(0-17.0)$ & 15 & Cambodia, Italy, Vietnam & $(44-46)$ \\
\hline Giardia & $50.0(0-100)$ & 13 & Cambodia, Eritrea & $(38,44)$ \\
\hline Helminth eggs & $9.7(2.80-11.1)$ & 4 & Cambodia & $(44)$ \\
\hline Toxocara spp. & $0(0-100)$ & 40 & Poland & $(42)$ \\
\hline Trichuris spp. & $0(0-33.3)$ & 40 & Poland & $(42)$ \\
\hline \multicolumn{5}{|l|}{ Virus } \\
\hline Norovirus & $30.0(23.3-40.0)$ & 3 & Multi-countryc, Spain & $(17)$ \\
\hline
\end{tabular}

${ }^{a}$ Median \% of produce samples positive.

${ }^{b}$ Number of groups of commodities.

'Data aggregated for more than one country.

'Shiga toxin-producing E. coli and Verotoxin-producing E. coli.

TABLE 3 | Pathogen prevalence on produce from packing facilities by pathogen type.

\begin{tabular}{|c|c|c|c|c|}
\hline Pathogen & $\begin{array}{c}\text { Median } \\
\text { prevalence }^{a} \\
\text { (range) }\end{array}$ & $\begin{array}{l}\text { Number } \\
\text { of groups } \\
\text { sampled }^{b}\end{array}$ & Sample country & Reference \\
\hline \multicolumn{5}{|l|}{ Bacteria } \\
\hline E. coli O157:H7 & $5.0(0-10.0)$ & 2 & $\begin{array}{l}\text { Multi-country }{ }^{\mathrm{c}} \text {, } \\
\text { South Africa }\end{array}$ & $(33,47)$ \\
\hline Listeria & $4.8(4.7-4.8)$ & 2 & United States & (31) \\
\hline Salmonella & $0(0)$ & 5 & $\begin{array}{l}\text { South Africa, } \\
\text { United States }\end{array}$ & $\begin{array}{c}(33,40,48, \\
49)\end{array}$ \\
\hline Shigella & $0(0)$ & 2 & $\begin{array}{l}\text { Multi-country }{ }^{c} \text {, } \\
\text { United States }\end{array}$ & $(37,47)$ \\
\hline $\begin{array}{l}\text { Staphylococcus } \\
\text { aureus }\end{array}$ & 5.00 & 1 & South Africa & (33) \\
\hline \multicolumn{5}{|l|}{ Virus } \\
\hline Hepatitis A & $11.1(0-50.0)$ & 6 & Mexico & (50) \\
\hline Norovirus & $10.0(0-50.0)$ & 6 & Mexico & (50) \\
\hline Rotavirus & $0(0-11.1)$ & 6 & Mexico & (50) \\
\hline
\end{tabular}

amedian \% of produce samples positive.

${ }^{b}$ Number of groups of commodities.

'Data aggregated for more than one country.

\section{Produce Type}

To compare the prevalence of human pathogens across fresh produce types, researchers stratified the results by herbs (Table 4), fruits (Table 5), and vegetables (Tables 6 and 7). The minority of articles sampled herbs (26\%, $n=10$ articles), followed by fruits (45\%, $n=17$ articles) and vegetables ( $82 \%, n=31$ articles). Among herbs, Vietnamese coriander (see Supplementary Materials) had the highest median prevalence of samples positive with bacteria $(41 \%, n=2)$, while marjoram had the highest median prevalence of samples positive with parasites $(17 \%, n=1)$. Among all herbs, only cilantro $(20 \%, n=3)$ and parsley $(50 \%, n=3)$ tested positive for viruses. Among fruits, peaches had the highest median prevalence of samples positive with bacteria $(2.5 \%, n=5)$, while raspberries had the highest median prevalence of samples positive with viruses $(40 \%, n=1)$. No parasites were detected on fruit. Among vegetables, wild cosmos had the highest median prevalence of samples positive with bacteria $(65 \%, n=4)$, while rhubarb had the highest median prevalence of samples positive for parasites $(33 \%, n=6)$. After pooling and comparing all commodities by herbs, fruits, and vegetables, there was no significant difference in the prevalence of pathogens by produce commodity type.

\section{DISCUSSION}

This research aimed to quantify the prevalence of contamination of human pathogens on fresh produce on farms and packing facilities. Overall, pathogens were detected on a low median percentage of fresh produce from farms and packing facilities. 
TABLE 4 | Pathogen prevalence by herb commodity.

\begin{tabular}{|c|c|c|c|c|c|}
\hline Commodity & $\begin{array}{c}\text { Median } \\
\text { prevalence } \\
\text { (range) }\end{array}$ & $\begin{array}{l}\text { Number } \\
\text { of groups } \\
\text { sampled }^{b}\end{array}$ & Pathogens tested & Sample country & Reference \\
\hline Basil & $6.8(1.1-12.5)$ & 2 & Cryptosporidium, Cyclospora & Iran, Vietnam & $(43,45)$ \\
\hline Coriander ${ }^{\mathrm{C}}$ & $8.3(0-70.0)$ & 11 & $\begin{array}{l}\text { Campylobacter, Cryptosporidium, Cyclospora, Escherichia coli O157:H7, } \\
\text { Hepatitis A, Listeria, norovirus, rotavirus, Salmonella }\end{array}$ & $\begin{array}{l}\text { Iran, Malaysia, Mexico, } \\
\text { United States, Vietnam }\end{array}$ & $\begin{array}{l}(14,15,22 \\
43,45,50)\end{array}$ \\
\hline Cress & 8.9 & 1 & Cryptosporidium & Iran & $(43)$ \\
\hline Fennel & 0 & 6 & Ascaris spp., Toxocara spp., Trichuris spp. & Poland & $(42)$ \\
\hline Dill & 0 & 5 & E. coli O157:H7, Listeria, Salmonella, Shiga toxin-producing E. coli & $\begin{array}{l}\text { Greece, Poland, } \\
\text { United States }\end{array}$ & $(22,25,28)$ \\
\hline $\begin{array}{l}\text { Indian } \\
\text { pennywort }\end{array}$ & 0 & 1 & Campylobacter & Malaysia & $(14)$ \\
\hline Marjoram & 16.6 & 1 & Cyclospora & Vietnam & $(45)$ \\
\hline Mint $^{d}$ & $8.1(7.6-8.5)$ & 2 & Cryptosporidium, Cyclospora & Iran, Vietnam & $(43,45)$ \\
\hline Parsley & $0(0-50.0)$ & 14 & $\begin{array}{l}\text { Ascaris spp., E. coli O157:H7, Hepatitis A, Listeria, norovirus, rotavirus, } \\
\text { Salmonella, Shiga toxin-producing E. coli, Toxocara spp., Trichuris spp. }\end{array}$ & $\begin{array}{l}\text { Greece, Lebanon, Mexico, } \\
\text { Poland, United States }\end{array}$ & $\begin{array}{c}(22,25,34 \\
42,50)\end{array}$ \\
\hline Sorrel & 0 & 6 & Ascaris spp., Toxocara spp., Trichuris spp. & Poland & $(42)$ \\
\hline
\end{tabular}

a Median \% of produce samples positive.

${ }^{b}$ Number of groups of commodities.

${ }^{\circ}$ Cilantro, coriander, and Vietnamese coriander.

${ }^{d}$ Mint and Vietnamese mint.

TABLE $\mathbf{5}$ | Pathogen prevalence by fruit commodity.

\begin{tabular}{|c|c|c|c|c|c|}
\hline Commodity & $\begin{array}{l}\text { Median prevalence } \\
\text { (range) }\end{array}$ & $\begin{array}{l}\text { Number } \\
\text { of groups } \\
\text { sampled }^{b}\end{array}$ & Pathogens tested & Sample country & Reference \\
\hline Blackberry & 0 & 1 & Listeria & Poland & (29) \\
\hline Blueberry & 0 & 1 & Listeria & Poland & (29) \\
\hline Cantaloupe & $1.7(0-40.0)$ & 4 & E. coli O157:H7, Listeria, Salmonella & Mexico, United States & $(22,36)$ \\
\hline Citrus $^{c}$ & $0(0)$ & 4 & Salmonella, Verotoxin-producing E. coli & Japan, United States & $(26,51)$ \\
\hline Kiwifruit & $0.50(0-3.9)$ & 6 & Pathogenic E. coli, Salmonella, Staphylococcus aureus & China & (39) \\
\hline Peach & $2.5(0-10.0)$ & 5 & E. coli O157:H7, Listeria, Salmonella, S. aureus & South Africa & (33) \\
\hline Raspberry & $0(0-40.0)$ & 5 & E. coli O157:H7, Listeria, norovirus, Salmonella & Multi-countrye, Poland & $(17,29)$ \\
\hline Strawberry & $0(0-30.0)$ & 15 & $\begin{array}{l}\text { Ascaris spp., E. coli O157:H7, Listeria, norovirus, Salmonella, } \\
\text { Toxocara spp., Trichuris spp. }\end{array}$ & Poland, Spain, United States & $(17,21,29,42)$ \\
\hline
\end{tabular}

a Median \% of produce samples positive.

${ }^{b}$ Number of groups of commodities.

'Orange, Satsuma mandarin, and tangerine.

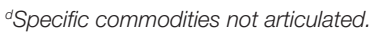

eData aggregated for more than one country.

This low percentage may result from the environment on the farms and in the packing facilities. Further, the enforcement of produce safety guidelines (e.g., US Good Agricultural Practices and GlobalGAP) may also limit the opportunities for pathogen contamination to occur on farms and in packing facilities (53-56). Specifically, the handling practices of the fresh produce may reduce the opportunities for the transfer of human pathogens to the fresh produce $(54,56)$. In addition, the environmental conditions such as sunlight, moisture, the physical characteristics of the surface of the produce, and temperature may limit the opportunities for pathogen persistence (57-59). Of note, results indicated a variance in the range of pathogen prevalence. Certain commodities, farms and packing facilities, and pathogens exhibited a wide range of pathogen prevalence (e.g., 0-100), while others had limited range (e.g., 0 ); however, most still had a median of $0 \%$ or low pathogen percentage. We hypothesize that this range may represent the naturally occurring ranges of contamination in the production environment among the specific produce commodity, farm and packing facility, and type of pathogen. A second hypothesis may be that the range of pathogen prevalence analyzed may be due to the inherent variability of pooling data extracted from individual articles across regions, detection methods, and times.

When pooling pathogens, viruses and parasites exhibited higher prevalence on fresh produce than bacteria. One explanation for these results may stem from foodborne viruses' (e.g., norovirus, hepatitis A, and rotavirus) increased ability to persist in the environment. A study examining the inactivation of caliciviruses reported the long-term survival (e.g., 1 week for $3 \log _{10}$ reduction in infectivity at $20^{\circ} \mathrm{C}$ ) at multiple, varying temperatures (60). In addition, a review of the survival of hepatitis A concluded 
TABLE 6 | Pathogen prevalence by vegetable commodity.

\begin{tabular}{|c|c|c|c|c|c|}
\hline Commodity & $\begin{array}{l}\text { Median } \\
\text { prevalence }^{a} \\
\text { (range) }\end{array}$ & $\begin{array}{l}\text { Number } \\
\text { of groups } \\
\text { sampled }^{b}\end{array}$ & Pathogens tested & Sample country & Reference \\
\hline Arugula & 0 & 3 & Escherichia coli O157:H7, Listeria, Salmonella & United States & $(22)$ \\
\hline Beetroot & $16.7(0-16.7)$ & 8 & $\begin{array}{l}\text { Ascaris spp., Salmonella, Shiga toxin-producing } \\
\text { E. coli, Toxocara spp., Trichuris spp. }\end{array}$ & Greece, Poland & $(25,28,42)$ \\
\hline Bok choi & 0 & 4 & E. coli O157:H7, Salmonella & United States & $(21)$ \\
\hline Brinjal & 20.0 & 1 & Listeria & India & $(32)$ \\
\hline Broccoli & 0 & 11 & $\begin{array}{l}\text { Ascaris spp., E. coli O157:H7, Listeria, Salmonella, Toxocara } \\
\text { spp., Trichuris spp. }\end{array}$ & $\begin{array}{l}\text { India, Poland, } \\
\text { United States }\end{array}$ & $(21,32,42)$ \\
\hline $\begin{array}{l}\text { Bulbous } \\
\text { vegetables }^{c}\end{array}$ & $0.9(0-1.7)$ & 2 & Listeria, Salmonella & Germany & $(30)$ \\
\hline Cabbage & $0(0-50.0)$ & 25 & $\begin{array}{l}\text { Ascaris spp., Campylobacter, E. coli O157:H7, Giardia, } \\
\text { Hepatitis A, Listeria, norovirus, rotavirus, Salmonella, } \\
\text { Shigella, Toxocara spp., Trichuris spp. }\end{array}$ & $\begin{array}{l}\text { Egypt, Eritrea, India, } \\
\text { Malaysia, Mexico, } \\
\text { Poland, South Africa, } \\
\text { United States }\end{array}$ & $\begin{array}{l}(14,21,29,31,32 \\
38,41,42,50,52)\end{array}$ \\
\hline Carrot & $0(0-42.9)$ & 15 & $\begin{array}{l}\text { Ascaris spp., Giardia, Salmonella, Shiga toxin-producing } \\
\text { E. coli, Shigella, Toxocara spp., Trichuris spp. }\end{array}$ & $\begin{array}{l}\text { Eritrea, Greece, Poland, } \\
\text { United States }\end{array}$ & $(25,28,37,38,42)$ \\
\hline Cauliflower & $0(0-20.0)$ & 7 & Ascaris spp., Listeria, Toxocara spp., Trichuris spp. & India, Poland & $(32,42)$ \\
\hline Celery & $0(0-25.0)$ & 8 & $\begin{array}{l}\text { Ascaris spp., Cyclospora, Shiga toxin-producing } \\
\text { E. coli, Toxocara spp., Trichuris spp. }\end{array}$ & Greece, Italy, Poland & $(25,42,46)$ \\
\hline Chappan-kaddu & 10.0 & 1 & Listeria & India & $(32)$ \\
\hline Chile pepper & 60.0 & 1 & Salmonella & Mexico & $(36)$ \\
\hline Chili & 10.0 & 1 & Listeria & India & $(32)$ \\
\hline Collards & 0 & 3 & E. coli O157:H7, Listeria, Salmonella & United States & $(22)$ \\
\hline Cowpea & 0 & 1 & Listeria & India & (32) \\
\hline Cucumber & $0(0-70.0)$ & 7 & Campylobacter, Cyclospora, E. coli O157:H7, Salmonella & $\begin{array}{l}\text { Italy, Malaysia, } \\
\text { United States }\end{array}$ & $(15,21,46)$ \\
\hline Cucurbits & 0 & 3 & Giardia, Salmonella, Shigella & Eritrea & (38) \\
\hline Dolichos bean & 20.0 & 1 & Listeria & India & (32) \\
\hline French beans & 0 & 6 & Ascaris spp., Toxocara spp., Trichuris spp. & Poland & $(42)$ \\
\hline Garlic & 0 & 1 & Shiga toxin-producing E. coli & Greece & (25) \\
\hline Green onion & $18.5(11.1-22.2)$ & 4 & Cryptosporidium, Hepatitis A, norovirus, rotavirus & Iran, Mexico & $(43,50)$ \\
\hline Green pepper & $0(0-2.3)$ & 4 & E. coli O157:H7, Salmonella & United States & $(21)$ \\
\hline Jalapeño pepper & 0 & 3 & Hepatitis A, norovirus, rotavirus & Mexico & $(50)$ \\
\hline
\end{tabular}

a Median \% of produce samples positive.

${ }^{b}$ Number of groups of commodities.

'Specific commodities not articulated.

that hepatitis A has a high half-life (e.g., 7.8 days at $20^{\circ} \mathrm{C}$ ), regardless of the environmental humidity, and persists on both inanimate and animate surfaces (61). For parasites, research studying the survival rate of Ascaris eggs reported an inactivation rate of 180 days at $30^{\circ} \mathrm{C}$ and a $\mathrm{pH}$ of 7 (62). An additional hypothesis for the increased prevalence of viruses and parasites over bacteria results from the methodologies for the detection of the pathogens. For example, molecular-based tests for the detection of viruses generally have higher sensitivity than traditional culture-based tests for the detection of bacteria (63) and microscopy-based tests for the detection of parasites (64).

This research had several strengths and limitations. In particular, the systematic review approach employed a robust strategy to answer the research question on pathogen prevalence. The collection of primary data to address this question would have required a large investment of time and resources worldwide. The diversity of commodities, agroecologies, and seasons represented in the dataset enable conclusions relevant to many produce production environments. An additional strength of the present study included the methodology of the search for articles. The researchers validated the search string with articles intended for inclusion, and multiple databases were examined to increase the article yield. The inclusion of all commodities, pathogens, or countries limited the researchers' biases and contributed to the sensitivity and comprehensiveness of the search. Further, two researchers independently performed each step of the data collection, which added to the rigor of the work. One limitation in the search and data extraction stage could include publication bias. Publication bias (a greater likelihood of publishing a positive, compared to a negative, pathogen prevalence) may have increased the bias of the extracted data toward positive outcomes. Interestingly, despite this possible publication bias, we observed low pathogen prevalence estimates. Additional limitations occurred in the analysis stage. For example, the data were pooled for analysis, which may have increased the variability and error in the estimates. The pooled data came from multiple pathogen detection assays across regions, methods, and times. In addition, concentration data reported as CFU or other measures of quantity of pathogens per positive sample was not included in the analyses. Due to the different laboratory detection methods and reporting units, the concentration data could not be accurately pooled, and 
TABLE 7 | Pathogen prevalence by vegetable commodity continued.

\begin{tabular}{|c|c|c|c|c|c|}
\hline Commodity & $\begin{array}{l}\text { Median } \\
\text { prevalence }^{\mathrm{a}} \\
\text { (range) }\end{array}$ & $\begin{array}{l}\text { Number } \\
\text { of groups } \\
\text { sampled }^{\mathrm{b}}\end{array}$ & Pathogens tested & Sample country & Reference \\
\hline Kale & 0 & 2 & Salmonella & Kenya & (35) \\
\hline Leafy greens & $0(0-25.0)$ & 7 & Escherichia coli 0157:H7, Giardia, Salmonella, Shigella & Eritrea, United States & $(21,38)$ \\
\hline Leek & $0(0-8.3)$ & 8 & $\begin{array}{l}\text { Ascaria spp., Cryptosporidium, Shiga toxin-producing E. coli, } \\
\text { Toxocara spp., Trichuris spp. }\end{array}$ & Greece, Iran, Poland & $(25,42,43)$ \\
\hline Lettuce $^{c}$ & $0(0-50.0)$ & 40 & $\begin{array}{l}\text { Bacillus cereus, Campylobacter, Cyclospora, E. coli O157:H7, } \\
\text { Hafnia alvei, Hepatitis A, Listeria, norovirus, rotavirus, Salmonella, } \\
\text { Shiga toxin-producing E. coli, Staphylococcus aureus, Toxocara spp., } \\
\text { Trichuris spp. }\end{array}$ & $\begin{array}{l}\text { Belgium, Brazil, Egypt, Eritrea, } \\
\text { Greece, Korea, Lebanon, } \\
\text { Mexico, Netherlands, Poland, } \\
\text { South Africa, United States, } \\
\text { Vietnam }\end{array}$ & $\begin{array}{c}(13,20,21,23 \\
25,27-29,34 \\
38,41,42,45 \\
50,52)\end{array}$ \\
\hline $\begin{array}{l}\text { Long yard } \\
\text { bean }\end{array}$ & $25.0(0-50.0)$ & 2 & Campylobacter & Malaysia & $(14,15)$ \\
\hline $\begin{array}{l}\text { Mustard } \\
\text { greens }\end{array}$ & 0 & 3 & E. coli O157:H7, Listeria, Salmonella & United States & $(22)$ \\
\hline Onion & $0(0-28.6)$ & 14 & $\begin{array}{l}\text { Ascaris spp., E.coli O157:H7, Listeria, Salmonella, Trichuris spp., } \\
\text { Toxocara spp. }\end{array}$ & $\begin{array}{l}\text { Greece, Poland, South Africa, } \\
\text { United States }\end{array}$ & $(18,21,25,42)$ \\
\hline Palak & 0 & 1 & Listeria & India & (32) \\
\hline Potato & $0(0-33.3)$ & 6 & Ascaris spp., Toxocara spp., Trichuris spp. & Poland & $(42)$ \\
\hline Pumpkin & 0 & 6 & Ascaris spp., Toxocara spp., Trichuris spp. & Poland & $(42)$ \\
\hline Radish & $0(0-16.7)$ & 3 & Campylobacter, Salmonella & Lebanon, Malaysia, Poland & $(14,28,34)$ \\
\hline Rhubarb & $33.3(0-33.3)$ & 6 & Ascaris spp., Toxocara spp., Trichuris spp. & Poland & $(42)$ \\
\hline $\begin{array}{l}\text { Root } \\
\text { vegetables }\end{array}$ & $1.5(0-3.0)$ & 2 & Listeria, Salmonella & Germany & (30) \\
\hline Salad & $0.8(0-1.6)$ & 2 & Listeria, Salmonella & Germany & (30) \\
\hline Sesame leaf & $0(0-7.9)$ & 10 & Bacillus cereus, E.coli O157:H7, Listeria, Salmonella, S. aureus & Korea & (13) \\
\hline Spinach $^{d}$ & $5.45(0-100)$ & 52 & $\begin{array}{l}\text { Bacillus cereus, Campylobacter, Cryptosporidium, Cyclospora, E.coli } \\
\text { O157:H7, Giardia, Helminth eggs, Listeria, Salmonella, Shiga toxin- } \\
\text { producing E.coli, Shigella, S. aureus }\end{array}$ & $\begin{array}{l}\text { Cambodia, Greece, Korea, } \\
\text { Malaysia, Multi-country, South } \\
\text { Africa, Spain, United States }\end{array}$ & $\begin{array}{l}(13,15,16,22 \\
25,44,47,52)\end{array}$ \\
\hline $\begin{array}{l}\text { Summer } \\
\text { squash }\end{array}$ & 0 & 4 & E. coli O157:H7, Salmonella & United States & $(21)$ \\
\hline Tomato $^{e}$ & $0(0-23.3)$ & 16 & $\begin{array}{l}\text { Campylobacter, E. coli O157:H7, Giardia, Listeria, norovirus, } \\
\text { Salmonella, Shiga toxin-producing E. coli, Shigella }\end{array}$ & $\begin{array}{l}\text { Eritrea, India, Malaysia, } \\
\text { Poland, Spain, United States }\end{array}$ & $\begin{array}{l}(14,17,21,24, \\
29,32,38)\end{array}$ \\
\hline Turnip & 0 & 6 & Ascaris spp., Toxocara spp., Trichuris spp. & Poland & $(42)$ \\
\hline Vegetables ${ }^{f}$ & 0 & 2 & E. coli O157:H7, Salmonella & United States & (19) \\
\hline Wild cosmos & $\begin{array}{c}65.0 \\
(30.0-90.0)\end{array}$ & 4 & Campylobacter & Malaysia & $(15)$ \\
\hline Winged bean & 6.7 & 1 & Campylobacter & Malaysia & $(15)$ \\
\hline $\begin{array}{l}\text { Young } \\
\text { beetroot } \\
\text { leaves }\end{array}$ & $0(0-100)$ & 6 & Ascaris spp., Toxocara spp., Trichuris spp. & Poland & $(42)$ \\
\hline Zucchini & $0(0-14.3)$ & 10 & Ascaris spp., E. coli O157:H7, Salmonella, Toxocara spp., Trichuris spp. & Poland, United States & $(21,42)$ \\
\hline
\end{tabular}

a Median \% of produce samples positive.

${ }^{b}$ Number of groups of commodities.

cLettuce and Romaine lettuce.

'Baby spinach, Roman rocket, spinach, and water spinach.

eTomato and cherry tomato.

'Specific commodities not articulated.

compared. This variation in detection and reporting methods presents an opportunity for standardization of pathogen detection techniques on produce commodities, especially for the less common parasitic pathogens and viral pathogens that are unculturable or are difficult to culture, like norovirus (3, 65-67). In addition, for the analysis, researchers assumed that stated percentage of pathogens detected represented the produce group sampled. However, the articles used different detection methodologies with varied limits of detection sensitivities and specificities, which limit the ability to detect true differences between groups. Future research that includes a larger dataset can address this issue.
Individuals involved in the fresh produce industry and food safety industry can use this review to identify locations and commodities with elevated contamination risk, and this information can contribute to ameliorate food safety practices. In addition, the low percentages of contamination on farms and packing facilities raise questions about its link with the frequency of produceassociated outbreaks. If a high frequency of produce-associated outbreaks is associated with a high percentage of pathogen contamination, then, most outbreaks probably do not originate from the farm and packing facility. Contamination of produce with pathogens may occur during other stages in the process between processing, handling, and consumption. Alternatively, 
a relationship between the frequency of produce-associated outbreaks and the frequency of pathogen contamination on produce may not exist. Instead, the outbreaks may result from the "perfect storm" of simultaneously occurring events (e.g., accidental pathogen contamination of fresh produce by a grower combined with conducive environmental conditions and protection of pathogens by the specific surface of a commodity (e.g., cantaloupe) and with packing practices that cross-contaminate pathogens). In addition, each pathogen strain has varying ranges of doses required to infect and sicken individuals and be propagated through personto-person outbreaks. For example, certain strains of norovirus have an ID50 of 18 viruses (68), and thus, small amounts of virus on multiple individual produce commodities may be sufficient to cause a norovirus produce-associated outbreak.

Additional primary research would not only strengthen the results of this systematic review study but also contribute to answering questions about the relationships of outbreaks to pathogen prevalence on farms and packing facilities. Specifically, cross-sectional studies that follow the same produce commodity across the farm-to-fork continuum (upon arrival from the packing facilities and at the time of placement on the markets' shelves) can quantify the percentage of pathogens at multiple stages. Further, additional research should continue to quantify the variability of pathogen contamination by commodity across multiple geographic locales and environmental conditions.

\section{CONCLUSION}

Foodborne illness due to consumption of contaminated produce causes significant burden around the world. Results indicated a low median percentage of fresh produce contaminated with pathogens $(0 \%)$.The quantification of the contamination of human pathogens on fresh produce on farms and in packing facilities improves our understanding of naturally occurring ranges of contamination

\section{REFERENCES}

1. World Health Organization. WHO Estimates of the Global Burden of Foodborne Diseases. Geneva: WHO (2015).

2. Gould LH, Walsh KA, Vieira AR, Herman K, Williams IT, Hall AJ, et al. Surveillance for foodborne disease outbreaks - United States, 1998-2008. MMWR Surveill Summ (2013) 62(2):1-34.

3. Fabiszewski de Aceituno A, Rocks J, Jaykus LA, Leon JS. Foodborne viruses. In: Labbe RG, editor. Guide to Foodborne Pathogens. Oxford: Wiley-Blackwell (2012). p. 352-76.

4. Leon JS, Moe C. Role of viruses in foodborne disease. In: Morris P, editor. Food Consumption and Disease Risk: Consumer-Pathogen Interactions. Cambridge: Woodhead Publishing Ltd (2006). p. 309-42.

5. Leon JS, Jaykus L, Moe C. Food safety issues and the microbiology of fruits and vegetables. In: Garcia S, editor. Microbiologically Safe Foods. Hoboken, NJ: John Wiley and Sons, Inc (2007). p. 255-90.

6. Fischer N, Bourne A, Plunkett D. Outbreak Alert! 2015: A Review of Foodborne Illnesses in the US from 2004-2013. Washington, DC: Center for Science in the Public Interest (2015).

7. Sivapalasingam S, Friedman CR, Cohen L, Tauxe RV. Fresh produce: a growing cause of outbreaks of foodborne illness in the United States, 1973 through 1997. J Food Prot (2004) 67(10):2342-53. doi:10.4315/0362-028x-67. 10.2342

8. Painter JA, Hoekstra RM, Ayers T, Tauxe RV, Braden CR, Angulo FJ, et al. Attribution of foodborne illnesses, hospitalizations, and deaths to food in the production environment. Additional research to collect primary data in cross-sectional studies will strengthen the conclusions, but this review identifies contamination prevalence to inform strategies to prevent future produce-associated foodborne illness.

\section{AUTHOR CONTRIBUTIONS}

AV developed the study design, completed data analysis, and wrote and revised all drafts including the final manuscript. BQ developed the study design, completed data analysis, and reviewed drafts including the final manuscript. HL developed the study design, completed data analysis and final manuscript formatting, edits, and reviewed the final manuscript draft. FB conceived the idea, the study design, and reviewed the final manuscript draft. KN contributed to the study design and reviewed the final manuscript draft. JL conceived the idea, the study design, completed data analysis, and reviewed drafts including the final manuscript.

\section{ACKNOWLEDGMENTS}

We thank Dr. Betsy Bihn (Cornell University) for the consultations of the interpretation of the study and Dr. Ben Lopman (Emory University) for guidance on the analysis. This material is based upon work that is supported by the National Institute of Food and Agriculture, U.S. Department of Agriculture, under award numbers 2010-85212-20608, 2011-67012-30762, 2011-68003-30395 (NoroCORE, Agriculture and Food Research Initiative Competitive Grant) and 2015-67017-23080.

\section{SUPPLEMENTARY MATERIAL}

The Supplementary Material for this article can be found online at http://www.frontiersin.org/articles/10.3389/fpubh.2018.00040/ full\#supplementary-material.

commodities by using outbreak data, United States, 1998 - 2008. Emerg Infect Dis (2013) 19(3):407-15. doi:10.3201/eid1903.111866

9. Lang L. Investigation of outbreak of infections caused by Salmonella Saintpaul. Gastroenterology (2008) 135(5):1440-1. doi:10.1053/j.gastro.2008.10.001

10. Centers for Disease Control and Prevention. Multistate Outbreaks of Salmonella Serotype Poona Infections Associated with Eating Cantaloupe from Mexico, United States and Canada, 2000-2002. Washington, DC: United States Department of Health and Human Services (2002). Contract No.: 46.

11. Ethelberg S, Lisby M, Bottiger B, Schultz AC, Villif A, Jensen T, et al. Outbreaks of gastroenteritis linked to lettuce, Denmark, January 2010. Euro Surveill (2010) 15(6):2-24. doi:10.2807/ese.15.06.19484-en

12. United States Food and Drug Administration. FDA Confirms Listeria monocytogenes on Jensen Farms' Rocky Ford-Brand Cantaloupes [Press Release]. Silver Spring: U.S. Food and Drug Administration (2011).

13. Tango CN, Choi NJ, Chung MS, Oh DH. Bacteriological quality of vegetables from organic and conventional production in different areas of Korea. J Food Prot (2014) 77(8):1411-7. doi:10.4315/0362-028x.jfp-13-514

14. Chai LC, Ghazali FM, Bakar FA, Lee HY, Suhaimi LR, Talib SA, et al. Occurrence of thermophilic Campylobacter spp. contamination on vegetable farms in Malaysia. J Microbiol Biotechnol (2009) 19(11):1415-20. doi:10.4014/ jmb.0901.0002

15. Khalid MI, Tang JY, Baharuddin NH, Rahman NS, Rahimi NF, Radu S. Prevalence, antibiogram, and cdt genes of toxigenic Campylobacter jejuni in salad style vegetables (ulam) at farms and retail outlets in Terengganu. J Food Prot (2015) 78(1):65-71. doi:10.4315/0362-028X.JFP-14-109 
16. Castro-Ibáñez I, Gil MI, Tudela JA, Ivanek R, Allende A. Assessment of microbial risk factors and impact of meterological conditions during production of baby spinach in the Southeast of Spain. Food Microbiol (2015) 49:173-81. doi:10.1016/j.fm.2015.02.004

17. Stals A, Baert L, Jasson V, Van Coillie E, Uyttendaele M. Screening of fruit products for norovirus and the difficulty of interpreting positive PCR results. J Food Prot (2011) 74(3):425-31. doi:10.4315/0362-028x.jfp-10-209

18. du Plessis EM, Duvenage F, Korsten L. Determining the potential link between irrigation water quality and the microbiological quality of onions by phenotypic and genotypic characterization of Escherichia coli isolates. J Food Prot (2015) 78(4):643-51. doi:10.4315/0362-028X.JFP-14-486

19. Mukherjee A, Speh D, Jones AT, Buesing KM, Diez-Gonzalez F. Longitudinal microbiological survey of fresh produce grown by farmers in the upper midwest. J Food Prot (2006) 69(8):1928-36. doi:10.4315/0362-028x-69.8.1928

20. Ceuppens S, Hessel CT, de Quadros Rodrigues R, Bartz S, Tondo EC, Uyttendaele M. Microbiological quality and safety assessment of lettuce production in Brazil. Int J Food Microbiol (2014) 181:67-76. doi:10.1016/j. ijfoodmicro.2014.04.025

21. Mukherjee A, Speh D, Dyck E, Diez-Gonzalez F. Preharvest evaluation of coliforms, Escherichia coli, Salmonella, and Escherichia coli O157:H7 in organic and conventional produce grown by Minnesota farmers. J Food Prot (2004) 67(5):894-900. doi:10.4315/0362-028x-67.5.894

22. Johnston LM, Jaykus LA, Moll D, Martinez MC, Anciso J, Mora B, et al. A field study of the microbiological quality of fresh produce. J Food Prot (2005) 68(9):1840-7. doi:10.4315/0362-028x-68.9.1840

23. Holvoet K, Sampers I, Seynnaeve M, Uyttendaele M. Relationships among hygiene indicators and enteric pathogens in irrigation water, soil and lettuce and the impact of climatic conditions on contamination in the lettuce primary production. Int J Food Microbiol (2014) 171:21-31. doi:10.1016/j. ijfoodmicro.2013.11.009

24. Pagadala S, Marine SC, Micallef SA, Wang F, Pahl DM, Melendez MV, et al. Assessment of region, farming system, irrigation source and sampling time as food safety risk factors for tomatoes. Int J Food Microbiol (2014) 196:98-108. doi:10.1016/j.ijfoodmicro.2014.12.005

25. Pinaka O, Pournaras S, Mouchtouri V, Plakokefalos E, Katsiaflaka A, Kolokythopoulou F, et al. Shiga toxin-producing Escherichia coli in Central Greece: prevalence and virulence genes of O157:H7 and non-O157 in animal feces, vegetables, and humans. Eur J Clin Microbiol Infect Dis (2013) 32(11):1401-8. doi:10.1007/s10096-013-1889-6

26. Izumi H, Poubol J, Hisa K, Sera K. Potential sources of microbial contamination of satsuma mandarin fruit in Japan, from production through packing shed. J Food Prot (2008) 71(3):530-8. doi:10.4315/0362-028x-71.3.530

27. BlaakH,vanHoek $A H$, Veenman C, vanLeeuwen $A E$, Lynch G, van OverbeekWM, et al. Extended spectrum B-lactamase- and constitutively AmpC-producing Enterobacteriaceae on fresh produce in the agricultural environment. Int $J$ Food Microbiol (2014) 16(8-169):8-16. doi:10.1016/j.ijfoodmicro.2013.10.006

28. KlapecT,Wojcik-FatlaA,CholewaA,CholewaG,DutkiewiczJ. Microbiological characterization of vegetables and their rhizosphere soil in Eastern Poland. Ann Agric Environ Med (2016) 23(4):559-65. doi:10.5604/12321966.1226846

29. Szymczak B, Szymczak M, Sawicki W, Dabrowski W. Anthropogenic impact on the presence of L. monocytogenes in soil, fruits, and vegetables. Folia Microbiol (Praha) (2014) 59(1):23-9. doi:10.1007/s12223-013-0260-8

30. Schwaiger K, Helmke K, Holzel CS, Bauer J. Comparative analysis of the bacterial flora of vegetables collected directly from farms and from supermarkets in Germany. Int J Environ Health Res (2011) 21(3):161-72. doi:10.1080/0960 3123.2010.515672

31. Prazak AM, Murano EA, Mercado I, Acuff GR. Prevalence of Listeria monocytogenes during production and postharvest processing of cabbage. J Food Prot (2002) 65(11):1728-34. doi:10.4315/0362-028x-65.11.1728

32. Soni DK, Singh M, Singh DV, Dubey SK. Virulence and genotypic characterization of Listeria monocytogenes isolated from vegetable and soil samples. BioMedical Central Microbiol (2014) 14:241. doi:10.1186/s12866-014-0241-3

33. Duvenage S, Korsten L. Assessment of foodborne pathogen presence in the peach supply chain and its potential risk to the end consumer. Food Control (2017) 78:374-82. doi:10.1016/j.foodcont.2017.03.003

34. Faour-Klingbeil D, Murtada M, Kuri V, Todd E. Understanding the routes of contamination of ready-to-eat vegetables in the Middle East. Food Control (2015) 62:125-33. doi:10.1016/j.foodcont.2015.10.024
35. Kutto EK, Ngigi MW, Karanja N, Kange'the E, Bebora LC, Lagerkvist CJ, et al. Bacterial contamination of kale (Brassica oleracea Acephala) along the supply chain in Nairobi and its environment. East Afr Med J (2011) 88(2):46-53.

36. Gallegos-Robles MA, Les-Loredo AM, Aivarez-Ojeda G, Vega A, Chew Y, Velarde S, et al. Identification of Salmonella serotypes isolated from cantaloupe and chile pepper production systems in Mexico by PCR-restriction fragment length polymorphism. J Food Prot (2008) 71(11):2217-22. doi:10.4315/ 0362-028x-71.11.2217

37. Endley S, Lu LG, Vega E, Hume ME, Pillai SD. Male-specific coliphages as an additional fecal contamination indicator for screening fresh carrots. J Food Prot (2003) 66(1):88-93. doi:10.4315/0362-028x-66.1.88

38. Srikanth R, Naik D. Prevalence of giardiasis due to wastewater reuse for agriculture in the suburbs of Asmara City, Eritrea. Int J Environ Health Res (2004) 14(1):43-52. doi:10.1080/09603120310001633912

39. Feng Y, Li G, Lv X, Xu Y, Wu Q, Shi C, et al. Prevalence, distribution, and diversity of Escherichia coli, Staphylococcus aureus, and Salmonella in kiwifruit orchards and processing plants. Foodborne Pathog Dis (2014) 11(10):782-90. doi:10.1089/fpd.2014.1759

40. Gomba A, Chidamba L, Korsten L. Prevalence and serovar diversity of Salmonella spp. in primary horticultural fruit production environments. Food Control (2016) 69:13-9. doi:10.1016/j.foodcont.2016.04.026

41. Maysa AIA, Abd-Elall AMM. Diversity and virulence associated genes of Salmonella enterica serovars isolated from wastewater agricultural drains, leafy greens producing farms, cattle and human along their courses. Revue de médicine vétérinaire (2015) 166(3):96-106.

42. Klapec T, Borecka A. Contamination of vegetables, fruits and soil with geohelminths eggs on organic farms in Poland. Ann Agric Environ Med (2012) 19(3):421-5.

43. Ranjbar-Bahadori SH, Mostoophi A, Shemshadi B. Study on Cryptosporidium contamination in vegetable farms around Tehran. Trop Biomed (2013) 30(2): 193-8.

44. Vuong TA, Nguyen TT, Klank LT, Phung DC, Dalsgaard A. Faecal and protozoan parasite contamination of water spinach (Ipomoea aquatic) cultivated in urban wastewater in Phnom Penh, Cambodia. Trop Med Int Health (2007) 12(12 Suppl):73-81. doi:10.1111/j.1365-3156.2007.01944.x

45. Tram NT, Hoang LM, Cam PD, Chung PT, Fyfe MW, Issac-Renton JL, et al. Cyclospora spp. in herbs and water samples collected from markets and farms in Hanoi, Vietnam. Trop Med Int Health (2008) 13(11):1415-20. doi:10.1111/j.1365-3156.2008.02158.x

46. Giangaspero A, Marangi M, Koehler AV, Papini R, Normanno G, Lacasella V, et al. Molecular detection of Cyclospora in water, soil, vegetables and humans in southern Italy signals a need for improved monitoring by health authorities. Int J Food Microbiol (2015) 211:95-100. doi:10.1016/j.ijfoodmicro.2015.07.002

47. Ilic S, Odomeru J, LeJeune JT. Coliforms and prevalence of Escherichia coli and foodborne pathogens on minimally processed spinach in two packing plants. J Food Prot (2008) 71(12):2398-403. doi:10.4315/0362-028x-71.12.2398

48. Endley S, Johnson E, Pillai SD. A simple method to screen Cilantro and parsley for fecal indicator viruses. J Food Prot (2003) 66(8):1506-9. doi:10.4315/0362-028X-66.8.1506

49. Pao S, Brown GE, Schneider KR. Challenge studies with selected pathogenic bacteria on freshly peeled Hamlin orange. J Food Sci (1998) 63(2):359-62. doi:10.1111/j.1365-2621.1998.tb15742.x

50. Felix-Valenzuela L, Resendiz-Sandoval M, Burgara-Estrella A, Hernández J, Mata-Haro V. Quantitative detection of hepatitis A, rotavirus and genogroup I norovirus by RT-qPCR in fresh produce from packinghouse facilities. J Food Safety (2012) 32(4):467-73. doi:10.1111/jfs. 12009

51. Pao S, Brown GE. Reduction of microorganisms on citrus fruit surfaces during packinghouse processing. J Food Prot (1998) 61(7):903-6. doi:10.4315/ 0362-028x-61.7.903

52. Jongman M. Genetic diversity and antibiotic resistance of Escherichia coli isolates from different leafy green production systems. J Food Prot (2016) 79(11):1846-53. doi:10.4315/0362-028X.JFP-16-117

53. U. S. Food and Drug Administration. Guidance for Industry: Guide to Minimize Microbial Food Safety Hazards for Fresh Fruits and Vegetables. Washington, DC: U.S. Food and Drug Administration (1998). p. 1-42.

54. GLOBAL G.A.P. Integrated Farm Assurance: All Farm Base-Crops Base-Fruit and Vegetables: Control Points and Compliance Criteria. Cologne: GLOBAL G.A.P (2017). 
55. Republic of South Africa: Department of Agriculture, Forestry, and Fisheries. Guideline on Contract Farming (Entry \& Intermediate Level GAP)-Horticulture. Pretoria: Department of Agriculture, Forestry and Fisheries (2012).

56. U.S. Food and Drug Administration. Food Safety Modernization Act Final Rule on Produce Safety, Standards for the Growing, Harvesting, Packing, and Holding of Produce for Human Consumption. 21 CFR Parts 16 and 112 (Vol. FDA-2011-N-0921) (2015). Available from: https://www.federalregister.gov/ documents/2015/11/27/2015-28159/standards-for-the-growing-harvestingpacking-and-holding-of-produce-for-human-consumption

57. Nyeleti C, Cogan T, Humphrey T. Effect of sunlight on the survival of Salmonella on surfaces. J Appl Microbiol (2004) 97:617-20. doi:10.1111/j.13652672.2004.02335.x

58. Ailes EC, Leon JS, Jaykus LA, Johnston LM, Clayton HA, Blanding S, et al. Microbial concentrations on fresh produce are affected by postharvest processing, importation, and season. J Food Prot (2008) 71(12):2389-97. doi:10.4315/ 0362-028X-71.12.2389

59. van Elsas JD, Semenov AV, Costa R, Trevors JT. Survival of Escherichia coli in the environment: fundamental and public health aspects. ISME J (2011) 5(2):173-83. doi:10.1038/ismej.2010.80

60. Duizer E, Bijkerk P, Rockx B, De Groot A, Twisk F, Koopmans M. Inactivation of caliciviruses. Appl Environ Microbiol (2004) 70(8):4538-43. doi:10.1128/ AEM.70.8.4538-4543.2004

61. Sattar SA, Jason T, Bidawid S, Farber J. Foodborne spread of hepatitis A: recent studies on virus survival, transfer and inactivation. Can J Infect Dis (2000) 11(3):159-63. doi:10.1155/2000/805156

62. Pecson BM, Barrios JA, Jimenez BE, Nelson KL. The effects of temperature, $\mathrm{pH}$, and ammonia concentration on the inactivation of Ascaris eggs in sewage sludge. Water Res (2007) 41(13):2893-902. doi:10.1016/j. watres.2007.03.040
63. Caliendo AM, Gilbert DN, Ginocchio CC, Hanson KE, May L, Quinn TC, et al. Better tests, better care: improved diagnostics for infectious diseases. Clin Infect Dis (2013) 57(Suppl 3):S139-70. doi:10.1093/cid/cit578

64. Roberts T, Barratt J, Harkness J, Ellis J, Stark D. Comparison of microscopy, culture, and conventional polymerase chain reaction for detection of Blastocystis sp. in clinical stool samples. Am J Trop Med Hyg (2011) 84(2):308-12. doi:10.4269/ajtmh.2011.10-0447

65. Perrin A, Loutreul J, Boudaud N, Bertrand I, Gantzer C. Rapid, simple and efficient method for detection of viral genomes on raspberries. J Virol Methods (2015) 224:95-101. doi:10.1016/j.jviromet.2015.08.005

66. Ettayebi K, Crawford SE, Murakami K, Broughman JR, Karandikar U, Tenge VR, et al. Replication of human noroviruses in stem cell-derived human enteroids. Science (2016) 353(6306):1387-93. doi:10.1126/science.aaf5211

67. Zou WY, Blutt SE, Crawford SE, Ettayebi K, Zeng XL, Saxena K, et al. Human intestinal enteroids: new models to study gastrointestinal virus infections. Methods Mol Biol (2017) 224:95-101. doi:10.1007/7651_2017_1

68. Teunis PF, Moe CL, Liu P, Miller SE, Lindesmith L, Baric RS, et al. Norwalk virus: how infectious is it? J Med Virol (2008) 80(8):1468-76. doi:10.1002/jmv.21237

Conflict of Interest Statement: The authors declare that the research was conducted in the absence of any commercial or financial relationships that could be construed as a potential conflict of interest.

Copyright (c) 2018 Van Pelt, Quiñones, Lofgren, Bartz, Newman and Leon. This is an open-access article distributed under the terms of the Creative Commons Attribution License (CC BY). The use, distribution or reproduction in other forums is permitted, provided the original author(s) and the copyright owner are credited and that the original publication in this journal is cited, in accordance with accepted academic practice. No use, distribution or reproduction is permitted which does not comply with these terms. 